\title{
Vertical transmission of dengue virus in the Yogyakarta airport area
}

\author{
Tri Baskoro Tunggul Satoto ${ }^{1 *}$, Antok Listyantanto ${ }^{2}$, Suzana Dewi Agustjahjani ${ }^{2}$, Hari Kusnanto Josef ${ }^{3}$ \\ and Barandi S. Widartono ${ }^{4}$
}

\begin{abstract}
Background: International Health Regulations controls international travel including human movement, disease vector, and imported items to prevent the spread of dengue, especially in seaports, airports, and border crossing posts. This study aimed to determine dengue Transovarial Transmission Index (TTI) and distribution of dengue virus in the areas around Adisucipto Airport of Yogyakarta, Indonesia.
\end{abstract}

Methods: The study was a descriptive analytic study with cross sectional design, conducted by mapping the spread of the dengue virus and identifying TTI in Adisucipto Airport. A total of 145 ovitraps were installed in both perimeter and buffer areas of the airport. Positive Ovitrap Index (OI), TTI, and serotype of dengue virus were examined. The TTI was identified using immunocytochemistry immunoperoxidase streptavidin biotin complex (IISBC) method in mosquito head squash preparations.

Results: Ol in the buffer area was 32 (45.1\%), whereas Ol in the perimeter area was 24 (32.4\%). The TTI in the buffer and perimeter areas were 21 (18.3\%) and 11 (18.9\%), respectively. The TTI was found greater in the Aedes aegypti population compared to the Aedes albopictus population, both in the perimeter area (20\% versus 16.7\%) and the buffer area (20.3\% versus 16.1\%). Dengue virus serotype-2 (DENV-2) and dengue virus serotype-3 (DENV-3) were predominantly found in Ae. aegypti and Ae. albopictus.

Conclusions: Buffer areas of Adisucipto Airport of Yogyakarta have higher risk as breeding sites for Aedes spp., predominantly DENV-2 and DENV-3 serotypes. High Ol shows that the areas are likely to have higher risk of developing dengue outbreak.

Keywords: Transovarial Transmission Index, Airport, Dengue, Aedes spp.

\section{Background}

In the last 50 years, the dengue disease has been spreading rapidly and extensively in the world following the geographical distribution to many countries, with the tendency of spreading from urban to rural areas. An estimated 50 million cases of dengue are found every year, and about 2.5 billion people are living in dengue endemic countries [1]. The World Health Organization (WHO) in 2005 issued a revision of the rules of international travel, known as the International Health Regulations (IHR) that included dengue as one of the diseases of Public Health Emergency of International Concern (PHEIC) that may have an impact

\footnotetext{
* Correspondence: tribaskoro@ugm.ac.id

${ }^{1}$ Center For Tropical Medicine, Faculty of Medicine, Universitas Gadjah Mada,

J. Farmako Sekip Utara, Yogyakarta, Indonesia

Full list of author information is available at the end of the article
}

on security problems of health and has the potential for causing an epidemic that can spread across borders between countries [1].

Tourists have a major role in the spread of dengue when entering areas inhabited with Aedes spp. mosquitoes [2], posing a risk of traveler viremia that could carry various strains of dengue serotypes. Study results showed an increasing trend of dengue cases per year (seasonal) with 522 travelers reported by The GeoSentinel Surveillance Network during the peak of dengue cases in Southeast Asia (June to September), Central Asia (October), South America (March), and The Caribbean (August, October), all of which indicate the relationship between travel and the occurrence of dengue epidemics [3]. In Southeast Asia, the annual morbidity rate has risen from 50 cases per 1000 travelers with dengue after traveling to a non-epidemic area

(c) The Author(s). 2018 Open Access This article is distributed under the terms of the Creative Commons Attribution 4.0 International License (http://creativecommons.org/licenses/by/4.0/), which permits unrestricted use, distribution, and reproduction in any medium, provided you give appropriate credit to the original author(s) and the source, provide a link to the Creative Commons license, and indicate if changes were made. The Creative Commons Public Domain Dedication waiver (http://creativecommons.org/publicdomain/zero/1.0/) applies to the data made available in this article, unless otherwise stated. 
to 159 cases per 1000 travelers during epidemics [3], although dengue transmission in the airport has not yet been reported until now.

The New Tokyo Narita International Airport Quarantine Post in Chiba Prefecture in year 2000 to 2002 had examined 233 passengers suspected of being infected with dengue virus: 1 case (4\%) out of 26 cases identified in year 2000,8 cases (12\%) out of 69 cases identified in year 2001, and 22 cases (16\%) out of 138 cases identified in year 2002 were confirmed as dengue infection [4]. Most of the passengers were infected after traveling from Southeast Asian and South Asian countries, one from African countries, one from Central American countries, one from Central and South American countries, and one from South American countries [4]. Fever screening in Taiwan Airport begun in July 2003 to June 2004 identified 40 dengue cases, among which 33 people $(82.5 \%)$ were confirmed as viremic patients [5]. During 2007 to 2010, sentinel surveillance in Taiwan Airport showed that most of the dengue-infected travelers had just returned from endemic areas around the Southeast Asian region, namely Indonesia (21.0 to $35.1 \%$ ), Vietnam (20.1 to 32.0\%), Thailand (5.0 to 13.0\%), the Philippines (9.0 to $12.3 \%$ ), Cambodia (4.1 to $8.0 \%$ ), Malaysia (2.0 to $4.1 \%$ ), Singapore (1.1 to $3.4 \%$ ), India (0 to $1.1 \%$ ), and only few travelers who had just returned from South America (0 to 0.7\%) [6]. In September 2013, in Germany, a traveler who had just returned from Japan was confirmed as having type 2 dengue virus infection; hence, the German Health Authority performed strict monitoring towards travel history of the travelers in order to evaluate risk potential of travelers having dengue virus infection [7].

International travel such as human movement, disease vector, and contaminated items that potentially cause widespread disease are regulated by the WHO in the International Health Regulations 2005 Article 9 (nine). Each country is required to perform dengue risk assessment to prevent the spread of dengue between countries by strengthening surveillance and supervision at the entrance areas, i.e., seaports, airports, and border crossing posts [8].

According to the Law Act 1 Year 1962 regarding Marine Quarantine and Act 2 Year 1962 regarding Sky Quarantine, as well as the IHR Year 2005 Article 2, all of which state that seaports and airports are obliged to be free from disease vectors and are required to perform disease control and prevention suitable to the potential risk factors without interfering with the commercial traffic [8]. Perimeter ports including seaports, airports, and rural ports are expected to be free from both larval stage and adult stage of Aedes aegypti mosquitoes, whereas in the buffer areas the following values are considered essential: House Index $(\mathrm{HI})$ of less than, or equal to $1 \%$, Breteau Index $(\mathrm{BI})$ of $<50$, biting rate of $<2.5$, and OI of $<15 \%$ [9].
This study was conducted to acquire information regarding the presence of Aedes spp. mosquitoes and the extent of transovarial transmission in the perimeter and buffer areas of Yogyakarta's Adisucipto Airport. The study was also intended to determine dengue Transovarial Transmission Index (TTI) and distribution of dengue virus in areas in and around Adisucipto Airport, Yogyakarta, Indonesia.

\section{Methods}

This research is a descriptive analytic study with a cross sectional design. The study was conducted by mapping the spread of dengue virus and identifying TTI in Adisucipto Airport of Yogyakarta, Indonesia (07 $47^{\prime} 17^{\prime \prime} \mathrm{S}$ and $110^{\circ} 25^{\prime} 54^{\prime \prime}$ E). The study was done in December 2015 to May 2016, during which rainy season took place.

Dengue cases were collected based on data retrieved from local primary health center. All of dengue cases were diagnosed with dengue non-structural protein 1 (NS-1) antigen test. However, serotypes of infecting dengue virus were unknown. The study was conducted by installing 145 ovitraps in both the perimeter and buffer areas of the airport. We defined the zones as the following definitions: perimeter area is $100-\mathrm{m}$ peripheral area from airport apron; buffer area is 400-m peripheral area from airport apron [9]. The study could only be performed at the northern and western area of the airport due to limited public access to the eastern and southern area.

Ovitrap Index (OI) is calculated from number of ovitraps with positive eggs divided by sum of ovitraps installed. Ovitraps were installed outdoors and indoors within 35-50 m distance. Positive OI and TTI of dengue virus were examined later on. After colonization of Aedes spp. eggs, TTI was identified using immunocytochemistry immunoperoxidase streptavidin biotin complex (IISBC) method in mosquito head squash preparations [10]. Rate of TTI was obtained by dividing the number of DENV-positive IISBC samples by total number of IISBC samples examined and was expressed as percentage [10]. The virus was identified through serotype examination by Lanciotti's RT-PCR. Transovarial transmission in both Aedes aegypti and Aedes albopictus mosquitoes obtained from indoor and outdoor ovitraps were compared. The analysis of OI distribution was conducted using the software ArcGIS 9.2 (Esri, New York) to provide mapping and spatial reasoning to yield location-based data. The data were entered into nearest neighbor analysis, resulting in the distance between each feature centroid and its nearest neighbor's centroid location. The $z$-score and $p$ value are measures of statistical significance that are used in determining whether or not to reject the null hypothesis: features are randomly distributed. 
The presence of high TTI value is considered an important mechanism for the maintenance of the virus in nature and may be associated in the occurrence of dengue epidemics and outbreak. High OI supports the potential of dengue outbreaks as well [11].

\section{Results}

Positive OI of Aedes spp. mosquitoes in the buffer area was 32 (45.1\%), with outdoor ovitraps showing greater proportion (50\%) compared to indoor ovitraps (37.9\%). OI in the buffer area was 32 (45.1\%), whereas OI in the perimeter area was $24(32.4 \%)$ as shown in Table 1 . The distribution of Aedes spp. mosquitoes based on positive OI in Yogyakarta's Adisucipto Airport was found evenly distributed in the surrounding areas, with the highest number of positive OI found in the zone 4 , the neighborhood 8 (Rukun Tetangga/RT 8) of village of Maguwoharjo (14 ovitraps or $9.6 \%$ ), and the least number of positive OI found in zone 4 of perimeter area, the B Terminal (2 ovitraps or 1.4\%) as shown in Fig. 1.

The nearest neighbor analysis shows that if the $z$-score is less than 1, the pattern exhibits clustering, whereas if the index is greater than 1, the trend is towards dispersion. The analysis of OI distribution resulted in $z$-score of -6.1 and $p$ value of $<0.001$ that indicates the tendency of clustered OI distribution. The shortest distance of positive ovitraps was $3.6 \mathrm{~m}$, while the farthest distance was $19 \mathrm{~m}$ with average distance of $13.2 \mathrm{~m}$. The results indicate that the distance is still within the range of mosquito disease transmission.

Through identification by examination using immunohistochemistry (IHC) method, as many as 11 samples (18.9\%) in the perimeter area and 21 samples (18.3\%) in the buffer area of Yogyakarta's Adisucipto Airport were found positive for transovarial transmission. The transovarial transmission was observed higher in percentage in Aedes aegypti mosquitoes, with 20 to $16.7 \%$ in the perimeter area and 20.3 to $16.1 \%$ in the buffer area (Table 2). In Aedes aegypti mosquitoes, positive transovarial transmissions were more commonly detected in samples obtained from indoor-installed ovitraps: 23.5 to $17.4 \%$ in the perimeter area and 25 to $14.8 \%$ in the buffer area. On the other hand, positive transovarial transmissions in Aedes albopictus mosquitoes were all found in samples

Table 1 Distribution of ovitrap installation in Adisucipto Airport of Yogyakarta

\begin{tabular}{|c|c|c|c|c|c|c|}
\hline \multirow[t]{2}{*}{ Location } & \multicolumn{2}{|c|}{ Situation } & \multicolumn{2}{|c|}{ (+) Eggs } & \multicolumn{2}{|l|}{ Ol (\%) } \\
\hline & Indoor & Outdoor & Indoor & Outdoor & Indoor & Outdoor \\
\hline Perimeter area & 40 & 34 & 12 & 12 & 30 & 35.3 \\
\hline Total number & 74 & & 24 & & 32.4 & \\
\hline Buffer area & 29 & 42 & 11 & 21 & 37.9 & 50 \\
\hline Total number & 71 & & 32 & & 45.1 & \\
\hline
\end{tabular}

from outdoor-installed ovitraps, with $16.7 \%$ in the perimeter area and $16.1 \%$ in the buffer area. Unfortunately, we did not perform further analysis to identify statistical significance of this difference in findings between mosquito species. Distribution of dengue virus in the Adisucipto Airport of Yogyakarta was predominantly found in zone 4 of the buffer area, the RT 8 of village of Maguwoharjo (4 cases or 12.5\%), and was least found in zone 2, the parking lot and common facility, and zone 3 , RT 7 of village of Maguwoharjo, with both areas having only 1 case detected (3.1\%). Dengue virus distribution tends to follow the distribution pattern of ovitraps. In both perimeter and buffer areas of the Adisucipto Airport, there were no dengue cases found. As described in Fig. 1, the shortest distance of dengue patients was $389 \mathrm{~m}$, whereas the farthest distance was $1050 \mathrm{~m}$.

The analysis of dengue virus distribution was conducted using the nearest neighbor analysis and resulted in $z$-score of -2.0 and $p$ value of 0.04 that indicates the tendency of clustered distribution. The shortest distance of positive ovitraps was $3.1 \mathrm{~m}$, while the farthest distance was $33 \mathrm{~m}$ with an average distance of $15.2 \mathrm{~m}$.

Dengue virus serotype examination was performed in dengue-positive Aedes spp. mosquito-colonized samples and in positive transovarial transmission samples, all of which were coded in species and location. The serotype examination was conducted using Lanciotti's RT-PCR method and resulted in the detection of DENV-2 and DENV-3 serotypes in Aedes aegypti and Aedes albopictus mosquitoes in Adisucipto Airport of Yogyakarta (Table 3). Data analysis on dengue virus serotype distribution in Yogyakarta's Adisucipto Airport resulted in $z$-score of 1.4 and $p$ value of 0.14 that indicates tendency of random dengue virus serotype distribution. The shortest distance of dengue virus serotype was $33 \mathrm{~m}$, while the farthest distance was $173 \mathrm{~m}$ with average distance of $94.1 \mathrm{~m}$ as shown in Fig. 2.

\section{Discussion}

Ovitrap Index (OI) in the buffer area was higher compared to that in the perimeter area. The results showed that the buffer areas have more potential as breeding sites of Aedes spp. mosquitoes. The distribution of Aedes spp. mosquitoes based on positive OI in Yogyakarta's Adisucipto Airport was found evenly distributed in the surrounding areas, with the highest number of positive OI found in the zone 4, the neighborhood 8 (Rukun Tetangga/RT 8) of village of Maguwoharjo. OI of $<5 \%$ shows that the distribution of Aedes spp. mosquitoes is least spread, while OI of 5-20\% shows that the Aedes spp. mosquitoes are moderately spread in the study area [12]. OI of $<10 \%$ indicates that the area has no risk in the development of dengue outbreak, whereas OI of $>10 \%$ indicates that the area has the potential for developing 


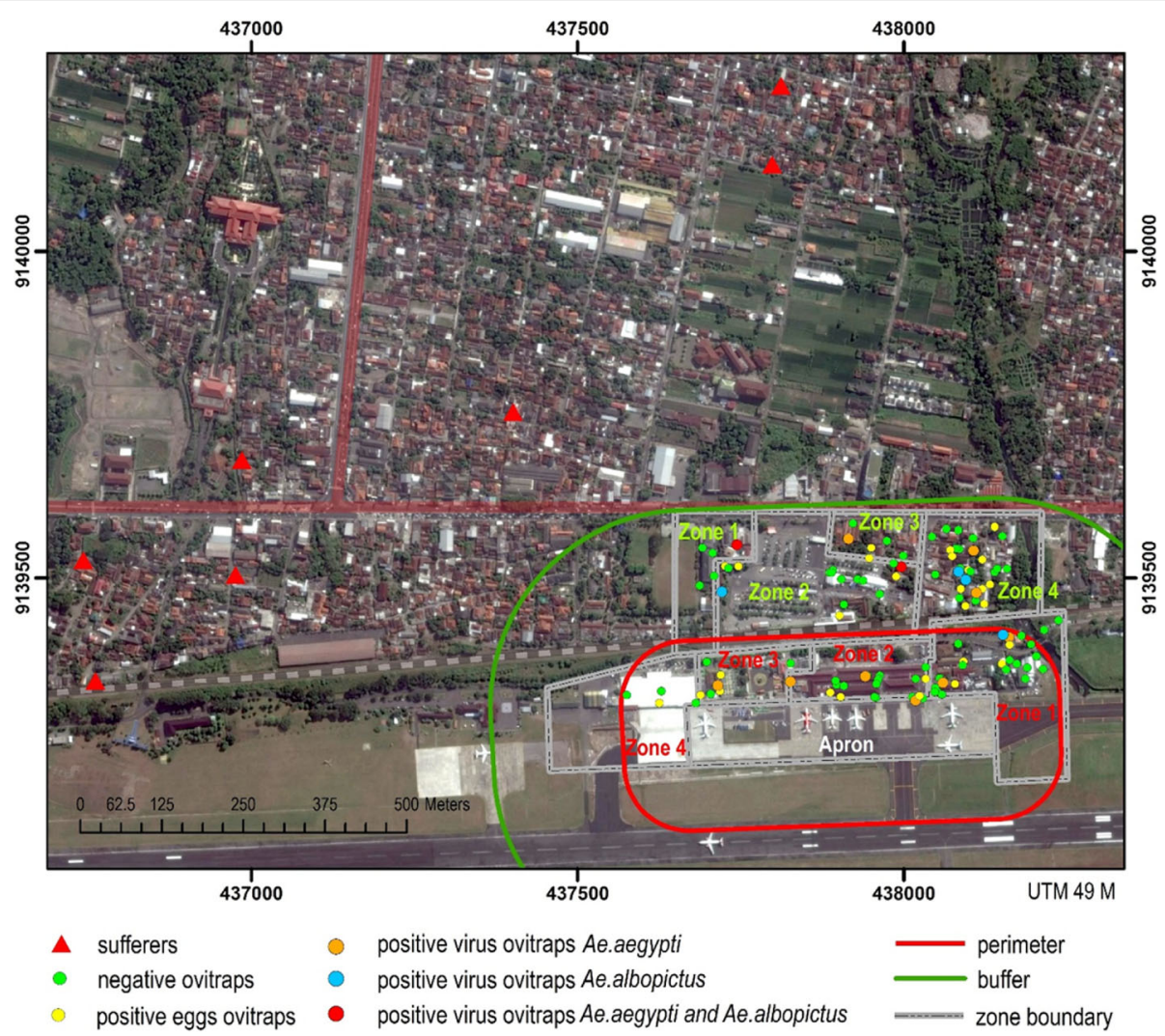

Fig. 1 Distribution map of dengue virus and dengue cases in Adisucipto Airport Yogyakarta in every Zones. Four zones in perimeter area are cargo $\log ($ zone 1), terminal A (zone 2), office (zone 3), and terminal B (zone 4), while four areas in buffer area (一) are terminal B (zone 1), parking and public facilities (zone 2), neighborhood 7 (zone 3), and neighborhood 8 (zone 4). Buffer area has more potential as breeding sites of Aedes spp. mosquitoes. The distribution of Aedes spp. mosquitoes based on positive Ovitrap Index in Yogyakarta's Adisucipto Airport was found evenly distributed in the area, positive eggs ovitraps, positive virus ovitraps Ae. aegypti, positive virus ovitraps Ae. albopictus, and positive virus ovitraps Ae. aegypti and Ae. albopictus, with the highest number of positive Ol found in the zone 4, the neighborhood 8 (RT 8) of village of Maguwoharjo. Negative ovitraps and dengue patients (sufferers) distribution may also be observed

dengue outbreak [13]. In the area of Yogyakarta's Adisucipto Airport, OI of $45.1 \%$ was found, which indicates potential for developing dengue outbreak.

The analysis of OI distribution resulted in $z$-score of 6.1 and $p$ value of $<0.001$ that indicates the tendency of clustered OI distribution. Through identification by using IHC method, the transovarial transmission was observed higher in percentage in Aedes aegypti mosquitoes in the perimeter area compared to that in the buffer area. The percentage alone presumes that Aedes aegypti mosquitoes may have a more dominant role in the transmission of dengue in the area of Adisucipto Airport of Yogyakarta. A similar study in Manado, Indonesia, also showed that the TTI in Aedes aegypti mosquitoes is significantly higher than that in Aedes albopictus mosquitoes [14]. Previous research established that Aedes aegypti mosquitoes have a major role in human dengue transmission [15]. A TTI rate of $20 \%$ allows the maintenance of highly stable vertical infection that persists for several generations [16].

Positive transovarial transmissions in Aedes aegypti mosquitoes were more commonly detected in samples obtained from indoor-installed ovitraps in the perimeter

Table 2 Analysis of transovarial transmission of Aedes spp. mosquitoes in Adisucipto Airport of Yogyakarta

\begin{tabular}{|c|c|c|c|c|c|c|}
\hline \multirow[t]{2}{*}{ Location } & \multicolumn{2}{|c|}{ Immunohistochemistry (IHC) } & \multicolumn{2}{|c|}{ Transovarial transmission } & \multicolumn{2}{|c|}{$\%$ transovarial transmission } \\
\hline & Ae. aegypti & Ae. albopictus & Ae. aegypti & Ae. albopictus & Ae. aegypti & Ae. albopictus \\
\hline Perimeter area & 40 & 18 & 8 & 3 & 20 & 16.7 \\
\hline Total number & 58 & & 11 & & 18.9 & \\
\hline Buffer area & 59 & 56 & 12 & 9 & 20.3 & 16.1 \\
\hline Total number & 115 & & 21 & & 18.3 & \\
\hline
\end{tabular}


Table 3 Serotypes of dengue virus in Aedes spp. mosquitoes in Adisucipto Airport of Yogyakarta

\begin{tabular}{|c|c|c|c|}
\hline \multirow[t]{2}{*}{ Location } & \multicolumn{2}{|l|}{ RT-PCR } & \multirow{2}{*}{$\begin{array}{l}\text { DENV } \\
\text { serotype }\end{array}$} \\
\hline & Aedes aegypti & Aedes albopictus & \\
\hline \multicolumn{4}{|c|}{ Perimeter area } \\
\hline $17 a$ & & 12 & DENV 2 \\
\hline $54 a$ & & 2 & DENV 2 and 3 \\
\hline \multicolumn{4}{|l|}{ Buffer area } \\
\hline $110 a$ & 12 & & DENV 2 and 3 \\
\hline 119a & 5 & & DENV 2 and 3 \\
\hline $132 \mathrm{a}$ & & 7 & DENV 2 and 3 \\
\hline $134 a$ & & 4 & DENV 2 and 3 \\
\hline $136 a$ & & 2 & DENV 2 \\
\hline
\end{tabular}

area. The results suggest that Aedes aegypti mosquitoes tend to do oviposition indoor rather than outdoor. A study in three localities in Malaysia also showed that ovitraps were more likely to yield positive results if installed indoor [17].

Positive transovarial transmissions in Aedes albopictus mosquitoes were all found in samples from outdoor-installed ovitraps. Distribution of dengue virus in the Adisucipto Airport of Yogyakarta was predominantly found in zone 4 of the buffer area, the RT 8 of village of Maguwoharjo. Dengue virus distribution tends to follow the distribution pattern of ovitraps. In both perimeter and buffer areas of the Adisucipto Airport, there were no dengue cases found. This result may be due to lack of good host immunity, higher activities of humans in the airport so that the mosquitoes were not able to bite very often [18], and low number of Aedes spp. mosquitoes in the Adisucptio Airport: 378 mosquitoes in $\pm 560,000 \mathrm{~m}^{2}$ perimeter and buffer areas. Other possible contributing factor is low TTI of dengue virus $(18.9 \%$ in perimeter area and $18.3 \%$ in buffer area). These TTI values are considered low as the study was conducted in endemic area and in rainy season, during which dengue transmission is on its peak; therefore TTI values should exceed 30\% [19]. As described in Fig. 1, the shortest distance of dengue patients was $389 \mathrm{~m}$, whereas the farthest distance was $1050 \mathrm{~m}$.

The analysis of dengue virus distribution was conducted using the nearest neighbor analysis and resulted in a $z$-score of -2.0 and $p$ value of 0.04 that indicates the tendency of clustered distribution. The shortest distance of

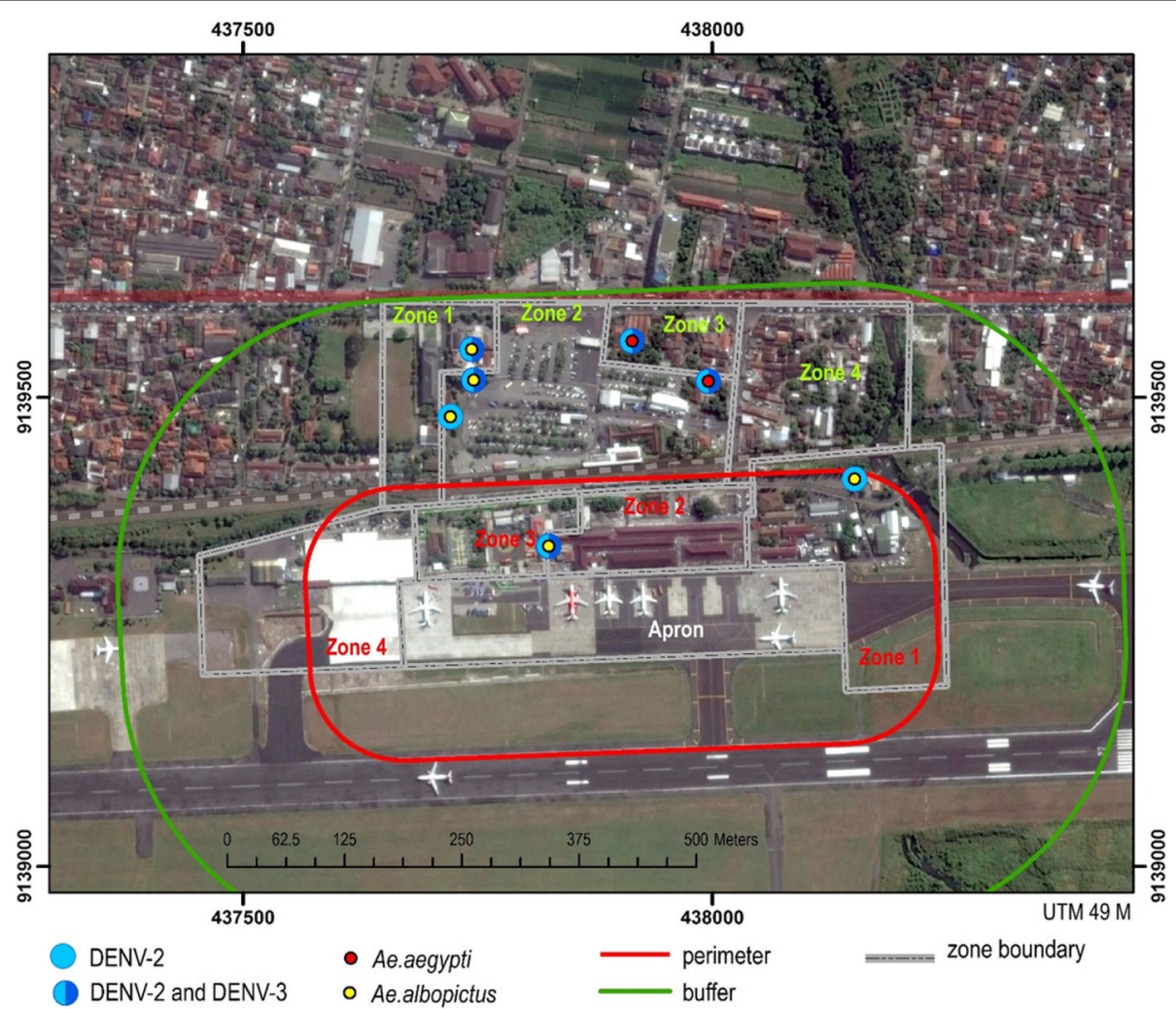

Fig. 2 Distribution map of dengue virus and dengue cases in Adisucipto Airport Yogyakarta. Four zones in perimeter area are cargo log (zone 1), terminal A (zone 2), office (Zone 3), and terminal B (zone 4), while four areas in buffer area are terminal B (zone 1), parking and public facilities (zone 2), neighborhood 7 (zone 3), and neighborhood 8 (zone 4). One spot was positive in perimeter area for DENV-2 and one spot positive for DENV-2 and DENV-3, both of which were also positive for Ae. albopictus. One spot was positive in buffer area for DENV-2 and two spots were positive for DENV-2 and DENV-3, all of which were also positive for Ae. albopictus. There were two spots positive in buffer area for DENV-2, DENV-3, and Ae. aegypti 
positive ovitraps was $3.1 \mathrm{~m}$, while the farthest distance was $33 \mathrm{~m}$ with average distance of $15.2 \mathrm{~m}$. Although no specific threshold values have been established for each arbovirus, absence of severe dengue cases in Thailand was noted when the density of Ae. aegypti eggs per ovitrap per week was less than two [20]. Moreover, despite using a different ovitrap, DENV transmission occurred in Taiwan when the density of eggs per house (two ovitraps per house) was around two [21]. In determining transmission of dengue virus, TTI is important in showing that dengue virus from infected female mosquitoes may be spread into the ovarii and transmitted to the next generation, whereas OI correlates with mosquito population and represents true mosquito infestations in the area [11, 22].

Dengue virus serotype examination was performed in dengue-positive Aedes spp. mosquito-colonized samples and in positive transovarial transmission samples, all of which were coded in species and location: DENV-2 and DENV-3. Similar results were obtained in Bantul, Indonesia, which showed the predominant serotypes of dengue virus in Aedes aegypti mosquitoes were DENV-3 (12 locations), followed by DENV-2 (3 locations), DEN-4 (1 location), and DENV-1 (0 location) [23]. Studies conducted in Thailand [24] and Singapore [25] showed that DENV-2 was the predominant serotype found. In areas with high dengue endemicity, the predominant serotypes were DENV-2 and DENV-3, while in areas with low dengue endemicity the prevalent serotypes were DENV-1 and DENV-2 [21]. A similar study conducted in 2007 to 2009 in Brazil reported that the highest number of mosquito larvae found was Aedes aegypti (3417 mosquitoes or 91\%), followed by Aedes albopictus (336 mosquitoes or 9\%), with detected serotypes of DENV-3 Aedes albopictus, DENV-2 Aedes aegypti, and DENV-2 and DENV-3 Aedes albopictus [26].

The study has several limitations. First, the study was conducted only once during rainy season, which would have been better if performed simultaneously in other season as well. Second, study area was limited only to areas open for public access, not including those areas that belonged to the Air Force and not open for public.

\section{Conclusion}

The study shows that buffer areas of Adisucipto Airport of Yogyakarta have higher risk as breeding sites for Aedes spp. mosquitoes, predominantly DENV-2 and DENV-3 serotypes. OI of 45.1 indicates that the area has the potential for developing dengue outbreak.

\footnotetext{
Abbreviations

Bl: Breteau Index; DENV-1: Dengue virus serotype-1; DENV-2: Dengue virus serotype-2; DENV-3: Dengue virus serotype-3; DENV-4: Dengue virus serotype-4; HI: House Index; IHR: International Health Regulations;

IISBC: Immunocytochemistry immunoperoxidase streptavidin biotin complex; NS-1: Non-structural protein 1: Ol: Ovitrap Index: PHEIC: Public Health Emergency of International Concern; RT: Rukun Tetangga (neighborhood);
}

RT-PCR: Reverse transcriptase-polymerase chain reaction; TTI: Transovarial Transmission Index; WHO: World Health Organization

\section{Acknowledgements}

Deepest gratitude is directed towards Angkasa Pura II, Agricultural Quarantine, and Airport Security of Yogyakarta's Adisucipto Airport, as well as towards the Port Health Quarantine of Yogyakarta who have been providing generous support. The authors would also like to acknowledge the Indonesian Ministry of Health for funding this study. Last but not the least, the authors would like to give appreciation to Dr. Ajib Diptyanusa for editing the final manuscript.

\section{Funding}

The funding body had no roles in the field survey, analysis, and

interpretation of data as well as in writing the manuscript.

\section{Availability of data and materials}

Data sharing is not applicable to this article as no datasets were generated or analyzed during the current study. The study was a part of AL's thesis. The data used in this article are not published elsewhere.

\section{Authors' contributions}

TBTS carried out the molecular genetic studies, conceived of the study, and participated in its design and coordination and in drafting the manuscript. AL carried out the field works and data analysis, while SDA participated in the surveillance. HKJ participated in the design of the study and performed the statistical analysis. BSW has provided assistance in designing and reviewing the map. All authors have read and approved the final manuscript.

\section{Authors' information}

TBTS is a member of Indonesian Entomological Association and is active in research in mosquito-borne diseases. AL and SDA are surveyors in Port Quarantine. HKJ is a professor in Public Health. BSW is an expert in map drawing

\section{Ethics approval and consent to participate}

Ethical approval was obtained from the Medical and Health Research Ethics Committee (MHREC), Faculty of Medicine Universitas Gadjah Mada, recognized by FERCAP.

\section{Competing interests}

The authors declare that they have no competing interests.

\section{Publisher's Note}

Springer Nature remains neutral with regard to jurisdictional claims in published maps and institutional affiliations.

\section{Author details}

${ }^{1}$ Center For Tropical Medicine, Faculty of Medicine, Universitas Gadjah Mada, J. Farmako Sekip Utara, Yogyakarta, Indonesia. ${ }^{2}$ Port Health Quarantine, Adisucipto Airport, Yogyakarta, Indonesia. ${ }^{3}$ Department of Public Health, Faculty of Medicine, Universitas Gadjah Mada, Yogyakarta, Indonesia. ${ }^{4}$ Department of Geographic Science, Faculty of Geography, Universitas Gadjah Mada, Yogyakarta, Indonesia.

Received: 12 August 2017 Accepted: 13 May 2018

Published online: 05 June 2018

\section{References}

1. World Health Organization. Dengue: guidelines for diagnosis, treatment, prevention and control. Geneva: World Health Organization; 2009.

2. Wilson ME. The traveller and emerging infections: sentinel, courier, transmitter. J Appl Microbiol. 2003;94 Suppl:1S-11S.

3. Schwartz E, Weld LH, Wilder-Smith A, von Sonnenburg F, Keystone JS, Kain $\mathrm{KC}$, et al. Seasonality, annual trends, and characteristics of dengue among ill returned travelers, 1997-2006. Emerg Infect Dis. 2008;14(7):1081-8.

4. Takahashi M, Miwa T, Yamada K, Sato Y, Ikawa K, Matsumoto Y, et al. Detection of dengue virus-infected patients among passengers at the quarantine station of the New Tokyo International Airport. Jpn J Infect Dis. 2002;55(6):215-6. 
5. Shu PY, Chien LJ, Chang SF, Su CL, Kuo YC, Liao TL, et al. Fever screening at airports and imported dengue. Emerg Infect Dis. 2005;11(3):460-2.

6. Kuan MM, Chang FY. Airport sentinel surveillance and entry quarantine for dengue infections following a fever screening program in Taiwan. BMC Infect Dis. 2012;12:182.

7. Schmidt-Chanasit J, Emmerich P, Tappe D, Gunther S, Schmidt S, Wolff D, et al. Autochthonous dengue virus infection in Japan imported into Germany, September 2013. Euro Surveill. 2014;19(3):1-3.

8. World Health Organization. International health regulations (2005). 2nd ed. Geneva: WHO Press; 2008.

9. General Directorate of Disease Control and Prevention. Manual of qurantine surveillance in port health office. Jakarta: Ministry of Health Republic of Indonesia; 2010.

10. Umniyati SR, Wahyono D, Artama WT, Mardihusodo SJ, Soeyoko MB, et al. Application of monoclonal antibody DSSC7 for detecting dengue infection in Aedes aegypti based on immunocytochemical streptavidin biotin peroxidase complex assay (ISBPC). Dengue Bulletin. 2008;32. New Delhi: WHO Regional Office for South- East Asia:83-98.

11. da Costa CF, Dos Passos RA, Lima JBP, Roque RA, de Souza Sampaio V, Campolina TB, et al. Transovarial transmission of DENV in Aedes aegypti in the Amazon basin: a local model of xenomonitoring. Parasit Vectors. 2017;10(1):249

12. Food and Environmental Hygiene Department HKSAR. 2006. https:/www.fehd gov.hk/english/pestcontrol/dengue_fever/index.html. Accessed 4 May 2016.

13. Lee HL. Aedes ovitrap and larval survey in several suburban communities in Selangor, Malaysia. Trop Biomed. 1992;9:29-34.

14. Sorisi AMH, Umniyati SR, Satoto TBT. Transovarial transmission index of denque virus on Aedes aegypti and Aedes albopictus mosquitoes in Malalayang District in Manado, North Sulawesi, Indonesia. TMJ. 2011;1(2):87-95.

15. Rosen L, Shroyer DA, Tesh RB, Freier JE, Lien JC. Transovarial transmission of dengue viruses by mosquitoes: Aedes albopictus and Aedes aegypti. Am J Trop Med Hyg. 1983;32(5):1108-19.

16. Tesh RB, Shroyer DA. The mechanism of arbovirus transovarial transmission in mosquitoes: San Angelo virus in Aedes albopictus. Am J Trop Med Hyg. 1980;29(6):1394-404

17. Wan-Norafikah O, Nazni WA, Noramiza S, Shafa'ar-Ko'ohar S, Heah SK, NorAzlina AH, et al. Distribution of Aedes mosquitoes in three selected localities in Malaysia. Sains Malays. 2012;41(10):1309-13.

18. World Health Organization. Vector surveillance and control at ports, airports, and ground crossings. Geneva: WHO Press; 2016.

19. Adams B, Boots M. How important is vertical transmission in mosquitoes for the persistence of dengue? Insights from a mathematical model. Epidemics. 2010;2(1):1-10

20. Mogi M, Choochote W, Khamboonruang C, Suwanpanit P. Applicability of presence-absence and sequential sampling for ovitrap surveillance of Aedes (Diptera: Culicidae) in Chiang Mai, northern Thailand. J Med Entomol. 1990; 27(4):509-14.

21. Wu HH, Wang CY, Teng HJ, Lin C, Lu LC, Jian SW, et al. A dengue vector surveillance by human population-stratified ovitrap survey for Aedes (Diptera: Culicidae) adult and egg collections in high dengue-risk areas of Taiwan. J Med Entomol. 2013:50(2):261-9.

22. Wong NS, Law CY, Lee MK, Lee SS, Lin H. An alert system for informing environmental risk of dengue infections. In: Lai PC, ASH M, editors. GIS for health and the environment: lecture notes in geoinformation and cartography. Berlin: Springer, Berlin, Heidelberg; 2007.

23. Satoto TBT, Umniyati SR, Astuti FD, Wijayanti N, Gavotte L, Devaux C, et al. Assessment of vertical dengue virus transmission in Aedes aegypti and serotype prevalence in Bantul, Indonesia. Asian Pac J Trop Dis. 2014;4(1):563-8.

24. Pongsiri $\mathrm{P}$, Themboonlers $\mathrm{A}$, Poovorawan $\mathrm{Y}$. Changing pattern of dengue virus serotypes in Thailand between 2004 and 2010. J Health Popul Nutr. 2012;30(3):366-70

25. Lee KS, Lo S, Tan SS, Chua R, Tan LK, Xu H, et al. Denque virus surveillance in Singapore reveals high viral diversity through multiple introductions and in situ evolution. Infect Genet Evol. 2012;12(1):77-85.

26. Martins VE, Alencar CH, Kamimura MT, de Carvalho Araujo FM, De Simone $\mathrm{SG}$, Dutra RF, et al. Occurrence of natural vertical transmission of dengue-2 and dengue-3 viruses in Aedes aegypti and Aedes albopictus in Fortaleza, Ceara, Brazil. PLoS One. 2012;7(7):e41386.

\section{Ready to submit your research? Choose BMC and benefit from:}

- fast, convenient online submission

- thorough peer review by experienced researchers in your field

- rapid publication on acceptance

- support for research data, including large and complex data types

- gold Open Access which fosters wider collaboration and increased citations

- maximum visibility for your research: over $100 \mathrm{M}$ website views per year

At BMC, research is always in progress.

Learn more biomedcentral.com/submissions 